\title{
CLC604 preferentially inhibits the growth of HER2-overexpressing cancer cells and sensitizes these cells to the inhibitory effect of Taxol in vitro and in vivo
}

\author{
JANG-CHANG LEE ${ }^{1,2}$, LI-CHEN CHOU ${ }^{1,8}$, JIN-CHEMG LIEN ${ }^{1}$, JIA-CHIUN WU ${ }^{3}$, CHI-HUNG HUANG ${ }^{4}$, \\ CHAO-HO CHUNG $^{1}$, FANG-YU LEE ${ }^{5}$, LI-JIAU HUANG ${ }^{1}$, SHENG-CHU KUO ${ }^{1,6}$ and TZONG-DER WAY ${ }^{3,7}$ \\ ${ }^{1}$ Graduate Institute of Pharmaceutical Chemistry, College of Pharmacy, China Medical University, Taichung; \\ ${ }^{2}$ School of Pharmacy, College of Pharmacy, China Medical University, Taichung; \\ ${ }^{3}$ Department of Biological Science and Technology, College of Life Sciences, China Medical University, Taichung; \\ ${ }^{4}$ Taiwan Advance Biopharm, Inc., Taipei; ${ }^{5}$ Yung-Shin Pharmaceutical Industry Co., Ltd., Tachia, Taichung; \\ ${ }^{6}$ Chinese Medicine Research and Development Center, China Medical University Hospital, Taichung; \\ ${ }^{7}$ Institute of Biochemistry, College of Life Science, National Chung Hsing University, Taichung; \\ ${ }^{8}$ Graduate School of Biotechnology, Hung Kuang University, Taichung, Taiwan, R.O.C.
}

Received February 21, 2013; Accepted April 25, 2013

DOI: $10.3892 / o r .2013 .2634$

\begin{abstract}
HER2 has become a solicitous therapeutic target in metastatic and clinical drug-resistant cancer. Here, we evaluated whether or not 1-benzyl-3-(5-hydroxymethyl-2-furyl) indazole (YC-1) and its furopyrazole and thienopyrazole analogues repress the expression of the HER2 protein. Among the test compounds, (1-benzyl-3-( $p$-hydroxymethylphenyl)-5methylfuro[3,2-c]pyrazol) (CLC604), an isosteric analogue of YC-1, significantly suppressed the expression of HER2, and preferentially inhibited cell proliferation and induced apoptosis in HER2-overexpressing cancer cells. Our results revealed that CLC604 reduced HER2 expression through a post-transcriptional mechanism and involvement of proteasomal activity. CLC604 disrupted the association of 90-kDa
\end{abstract}

Correspondence to: Professor Tzong-Der Way, Department of Biological Science and Technology, College of Life Sciences, China Medical University, No. 91 Hsueh-Shih Road, Taichung 40402, Taiwan, R.O.C.

E-mail: tdway@mail.cmu.edu.tw

Professor Sheng-Chu Kuo, Graduate Institute of Pharmaceutical Chemistry, College of Pharmacy, China Medical University, No. 91 Hsueh-Shih Road, Taichung 40402, Taiwan, R.O.C.

E-mail:sckuo@mail.cmu.edu.tw

Abbreviations: 17-AAG, 17-(allylamino)-17-demethoxygeldanamycin; CHX, cycloheximide; CLC604, (1-benzyl-3-( $p$-hydroxymethylphenyl)5-methylfuro[3,2-c]pyrazol); EGFR, epithelial growth factor receptor; HIF-1 $\alpha$, hypoxia-inducible factor- $1 \alpha$; Hsp90, 90-kDa heat shock protein; MG132, Z-Leu-Leu-Leu-al; MTT, 3-(4,5-dimethylthiazol2-yl)-2, 5-diphenyltetrazolium bromide; PBS, phosphate-buffered saline; YC-1, 1-benzyl-3-(5-hydroxymethyl-2-furyl)indazole

Key words: HER2, YC-1, CLC604, Hsp90, clinical drug heat shock protein (Hsp90) with HER2 resulting from the inhibition of Hsp90 ATPase activity. Moreover, we found that CLC604 significantly enhanced the antitumor efficacy of clinical drugs against HER2-overexpressing tumors and efficiently reduced HER2-induced drug resistance in vitro and in vivo. These findings suggest that CLC604 should be developed further as a novel antitumor drug candidate for the treatment of drug-resistant cancer.

\section{Introduction}

Breast and ovarian cancer remain major health concerns, and are the most common malignancies diagnosed in women (1). Approximately $30 \%$ of metastatic human breast and ovarian cancer are associated with the overexpression or amplification of the HER2 receptor $(2,3)$. HER 2 is a $185-\mathrm{kDa}$ transmembrane receptor with tyrosine kinase activity and may dimerize with other epithelial growth factor receptor (EGFR) family members, including EGF receptors HER1, HER3 and HER4. Overexpression of HER2 has been frequently found in various types of human cancers, such as breast, gastric, lung, ovarian, kidney and bladder cancers. HER 2 overexpression in cancer cells have been proven to enhance cell proliferation, increase the tendency for metastasis, shorten disease-free survival, induce clinical drug-resistance, and lower overall survival rates $(4,5)$.

HER2-mediated signaling has also been demonstrated to be involved in the anti-apoptosis induced by certain pro-apoptotic stimuli (4). Moreover, previous studies have indicated that reducing the HER2 expression in cancer cells may attenuate anti-apoptotic signaling and suppress HER2mediated malignant phenotypes. Therefore, HER 2 is not only a potent oncogene, but also an excellent therapeutic target for breast and ovarian cancers. Monoclonal antibodies were the first anti-HER2 strategy to be used for clinical therapy (6). 
Trastuzumab (Herceptin), a recombinant humanized monoclonal antibody, is used to treat metastatic breast cancer via directly counteracting the extracellular domain of HER2. Although Herceptin is known as a successful therapeutic antibody, only one-third of HER2-overexpressing metastatic breast cancers respond to Herceptin single-agent therapy, while almost two-thirds respond to combined Taxol-Herceptin regimens. However, these responses are short-lived, averaging less than 1 year (7), and recurring resistance for Herceptin has been observed in the majority of patients within 1 year $(8,9)$. Identification of the potential mechanisms of Herceptinresistance can be extremely helpful for the development of new compounds that may overcome such resistance and demonstrate additive/synergistic antitumor effects when administered in association with Herceptin.

The $90-\mathrm{kDa}$ heat shock protein 90 (Hsp90) is a protein chaperone whose functions are to promote the maturation and conformational stabilization of a subset of cellular proteins, and it is crucial in signal transductions of cell proliferation and survival (10). During client processing, ATP binding to Hsp90 drives momentous conformational change in the chaperone and ultimately leads to ATP hydrolysis (11). HER2, a client protein of Hsp90, is known to interact with Hsp90 to acquire proper protein function; therefore, using inhibitors of Hsp90 to target HER 2 through dissociation of HER 2 from the chaperone leads to degradation of HER 2 by a proteasome-dependent manner $(11,12)$. The Hsp90 inhibitors such as geldanamycin and its less cytotoxic analogue, 17-(allylamino)-17-demethoxygeldanamycin (17-AAG), through binding to an ATP pocket in the $\mathrm{NH}_{2}$-terminal domain of this protein, inhibits the Hsp90 chaperone function $(11,13)$.

Numerous structure-activity relationships and biochemical assay data indicate that 1-benzyl-3-(5-hydroxymethyl-2-furyl) indazole (YC-1) displays high potential as a new anticancer drug candidate $(14,15)$. In vivo xenograft studies have also revealed that YC-1 exhibits marked antitumor activity against various cancer cell lines and prolongs the survival time of tumor-bearing mice, but without evident toxic effects $(16,17)$. The anticancer effect of YC-1 appears to be a consequence of its multiple actions, including anti-inflammation activity, suppression of the hypoxia-inducible factor- $1 \alpha(\mathrm{HIF}-1 \alpha)$ expression, influence on the differentiation of stem cells, and promotion of NK cell differentiation by activating the p38-MAPK pathway (18-20).

In our previous study, we reported that YC-1 furopyrazole and thienopyrazole isosteric analogues exhibit greater cytotoxicity against HL-60 cells than YC-1, and their physiochemical properties and biological mechanisms appear to be at variance to YC-1 $(15,21)$. As part of our continuing search for potential anticancer drug candidates among YC-1 analogues, we further investigated the anticancer activity and biological mechanisms of various YC-1 isosteric analogues in vitro and in vivo. In this present study, 8 furopyrazole and thienopyrazole compounds were chosen for evaluation of their effect on HER2 expression. Among them, CLC604 (1-benzyl3-( $p$-hydroxymethylphenyl)-5-methylfuro[3,2-c]pyrazol) was more sensitive to HER2-overexpressing cancer cells. Thus, among the tested YC-1 analogues, CLC604 was considered to be the most promising compound for further study of its physiochemical properties and biological mechanisms.
Combinative cancer therapy has become a common approach for increasing curative rates and decreasing side effects leading to the improvement in the quality of life of patients. Consequently, we performed in vitro and in vivo synergistic treatment on breast cancer cells with HER 2 overexpression using a combination of CLC604 with a low-dose of clinical drugs (Taxol, doxorubicin, and etoposide) in contrast with single-agent treatment. We found that CLC604 suppressed the growth of HER2-overexpressing breast tumors in $\mathrm{MCF} / \mathrm{Her} 18$ tumor-bearing mice and increased the potency of Taxol.

\section{Materials and methods}

Chemicals and reagents. YC-1, and furopyrazole and thienopyrazole analogues of YC-1 were synthesized in our laboratory. Cell culture materials were obtained from Invitrogen Life Technologies (Burlington, Ontario, Canada). Antibodies and reagents were purchased from commercial sources: antibodies against Akt and c-Raf were purchased from Cell Signaling Technology, Inc. (Beverly, MA, USA). An antibody against Hsp90 was from BD Transduction Laboratory and antibodies against cyclin-dependent kinase 4 (CDK4) and HER2 (9G6) were from Santa Cruz Biotechnology, Inc. (Santa Cruz, CA, USA). An antibody against HER2 (Ab3) was obtained from Calbiochem Company (San Diego, CA, USA). Anti-mouse and anti-rabbit antibodies conjugated to horseradish peroxidase, a $\beta$-actin antibody, an $\alpha$-tubulin antibody, 3-(4,5-dimethylthiazol-2-yl)-2, 5-diphenyltetrazolium bromide (MTT), actinomycin D (AcD), cycloheximide, 17-AAG, Z-Leu-LeuLeu-al (MG132), G418, etoposide (E1383), Taxol (T7402), and doxorubicin (D1515) were obtained from Sigma Chemical Co. (St. Louis, MO, USA). Protein A/G-agarose was from Upstate Company and SeaPlaque Agarose (low melting temperature agarose) was purchased from Lonza (Rockland, ME, USA).

Cell lines and cell cultures. The human breast and ovarian cancer cell lines used in this study were SKOV3, SKOV3.ip1, MDA-MB-453 and SKBr3, all of which overexpress HER2. MCF-7, MDA-MB-231 and MDA-MB-435/neo cells all express a basal level of HER2. The HBL-100 cell line, which is derived from normal human breast tissue, was transformed by SV40 large T antigen and expresses a basal level of HER2. In addition, we used MCF-7/HER18 and MDA-MB-435/HER2 cells; MCF-7 and MDA-MB-435 were stably transfected with pSV2/HER2 and had HER2 overexpression. MDA-MB-453, MDA-MB-231 and MCF-7 cells were grown in Dulbecco's modified Eagle's medium (DMEM) supplemented with $10 \%$ fetal bovine serum (FBS) and SKBr3 was cultured in MyCoy's 5A medium (modified). The other cells were cultured in DMEM/F12 supplemented with $10 \%$ FBS. Cells were grown in a humidified incubator at $37^{\circ} \mathrm{C}$ under $5 \% \mathrm{CO}_{2}$ in air.

Preparation of cell lysates, immunoblotting and immunoprecipitation. Cells were treated with various agents, as indicated in the figure legends. After treatment, cells were washed with cold phosphate-buffered saline (PBS) and lysed with a lysis buffer [1\% Triton X-100, $10 \%$ glycerol, $10 \mu \mathrm{g} / \mathrm{ml}$ leupeptin, $1 \mathrm{mmol} / 1$ sodium orthovanadate, $1 \mathrm{mmol} / 1$ EGTA, $10 \mathrm{mmol} / \mathrm{l} \mathrm{NaF}, 1 \mathrm{mmol} / 1$ sodium pyrophosphate, $100 \mu \mathrm{mol} / \mathrm{l}$ 
$\beta$-glycerophosphate, $20 \mathrm{mmol} / \mathrm{l}$ Tris- $\mathrm{HCl}$ (pH 7.9), $137 \mathrm{mmol} / 1$ $\mathrm{NaCl}, 5 \mathrm{mmol} / \mathrm{l}$ EDTA, and a protease inhibitor $(1: 10,000)]$ for immunoblotting. For immunoprecipitation, cells were lysed with RIPA-B buffer [1\% Triton X-100, $150 \mathrm{mmol} / \mathrm{l} \mathrm{NaCl}$, $20 \mu \mathrm{mol} / 1 \mathrm{NaHPO}_{4}(\mathrm{pH} 7.4), 0.1 \mathrm{mmol} / 1$ sodium orthovanadate and $1 \mathrm{~mol} / 1 \mathrm{NaF}$, protease inhibitor $(1: 2,500)]$. One milligram of each sample was mixed with $1 \mu \mathrm{g}$ antibody and $50 \mu \mathrm{l}$ protein $\mathrm{A}$ agarose at $4^{\circ} \mathrm{C}$ for $3 \mathrm{~h}$. The immunoprecipitates were washed in RIPA-B buffer without a protease inhibitor, eluted with the SDS sample loading buffer, and processed for immunoblot analyses, as described previously (22). For preparation of Triton X-100-soluble and -insoluble fractions, cells were lysed with a lysis buffer containing $1 \%$ Triton $\mathrm{X}-100$, as described above. After removal of Triton X-100-soluble cell lysate supernatants by centrifugation, the pellets were washed once with the lysis buffer, and a $1 \mathrm{X}$ SDS loading buffer $(50 \mu \mathrm{l})$ was then added to the pellets and heated at $95^{\circ} \mathrm{C}$ for $15 \mathrm{~min}$ to dissolve the Triton X-100-insoluble proteins.

Determination of cell viability by MTT assay. The effects of YC-1, furopyrazole and thienopyrazole analogues of YC-1, and 3 clinical drugs (doxorubicin, etoposide and Taxol) on cell viability were examined by MTT assay. Cells were treated with various doses of the drugs for the indicated times, and the MTT dye was then added to each well. After a 4-h incubation, the growth medium was removed and the formazan crystals, generated by oxidation of the MTT dye by cell mitochondria, were dissolved in $0.04 \mathrm{~N} \mathrm{HCl}$ in isopropanol. The absorbance was measured at $570 \mathrm{~nm}$, and the cell survival ratio was expressed as a percentage of the control viability (23).

Flow cytometric analysis. Cells were treated with various agents for the indicated times, harvested by trypsinization, fixed with $70 \%(\mathrm{v} / \mathrm{v})$ ethanol at $4^{\circ} \mathrm{C}$ for $30 \mathrm{~min}$, and washed twice with phosphate-buffered saline (PBS). After centrifugation, the cells were incubated with $0.1 \mathrm{ml}$ of a phosphate-citric acid buffer [0.2 $\mathrm{M} \mathrm{NaHPO}_{4}$ and $0.1 \mathrm{M}$ citric acid (pH 7.8)] for $30 \mathrm{~min}$ at room temperature. The cells were then centrifuged and re-suspended in $0.5 \mathrm{ml}$ propidium iodide (PI) solution comprising Triton X-100 (0.1\%, v/v), RNase $(100 \mathrm{mg} / \mathrm{ml})$ and PI $(80 \mathrm{mg} / \mathrm{ml})$. The percentage of apoptosis was analyzed with FACScan and CellQuest software (Becton-Dickinson, Mountain View, CA, USA).

Soft agar colony formation assay. The effects of CLC604 on the soft agar colony formation of various human breast cell lines were investigated. Briefly, cells $\left(1 \times 10^{4}\right)$ were seeded in a 6 -cm culture dish containing $0.35 \%$ low-melting agarose over a $0.7 \%$ agarose layer in the presence of varying concentrations of CLC604 or a control vehicle and incubated for 3 weeks at $37^{\circ} \mathrm{C}$. Colonies were stained with p-iodonitrotetrazolium violet $(1 \mathrm{mg} / \mathrm{ml})$, and those colonies larger than $100 \mu \mathrm{m}$ were measured. The differences in the effects of CLC604 between cell lines expressing a basal level of HER2 and overexpressing HER2 were evaluated using ANOVA.

Cell transfection. Plasmid pSV2-erbB2, a constitutive expression vector, carries 4.4-kb full-length human HER2 cDNA under the control of the SV40 promoter/enhancer sequence. Cells $\left(6 \times 10^{5}\right)$ were transfected with $5 \mu \mathrm{g}$ of DNA mediated by
$21 \mu 1$ of a Lipofectin reagent. Experiments were performed after transfection.

Immunofluorescence assay. MDA-MB-453 cells were placed on cover slides in 6-well plates. Experiments were performed $24 \mathrm{~h}$ after cell attachment. Cells were fixed in PBS containing $4 \%$ formaldehyde for 10-15 min at room temperature. Cells were rinsed with PBS 2-3 times followed by blocking with 5\% BSA (Sigma-Aldrich, St. Louis, MO, USA) for $30 \mathrm{~min}$. Incubations were performed with primary antibodies diluted in a blocking buffer at $4^{\circ} \mathrm{C}$ overnight, after which cover slides were washed and incubated for $30 \mathrm{~min}$ with the isothiocyanate (FITC)-conjugated secondary antibodies (Chemicon, Temecula, CA, USA) diluted in blocking buffer. Cover slides were washed and mounted. Fluorescence was visualized using a Nikon Optiphot-2 microscope.

In vitro Hsp90 assay. Hsp90 proteins expressed as His6-tagged fusions were purified as described previously using TALON metal-affinity chromatography, Q-Sepharose ion-exchange, and Superdex 75, 200, or Sephacryl 400HR gel-filtration chromatography. Proteins were concentrated in $20 \mathrm{mM}$ Tris (pH 7.5) containing $0-25 \mathrm{mM} \mathrm{NaCl}, 1 \mathrm{mM}$ EDTA and $0.5 \mathrm{mM}$ DTT. The Hsp90 ATPase assay was performed as previously described (24).

In vivo studies. The animals used in this study were purchased from the National Laboratory Animal Breeding and Research Center (Taipei, Taiwan) following China Medical University Institutional Animals Ethic Committee clearance (99-151-N). Female BALB/c SCID mice (18-20 g; 6-8 weeks of age) were purchased from the National Animal Center, Taipei, Taiwan, and maintained in pressurized ventilated cages according to institutional regulations. Each SCID mouse was subcutaneously inoculated in the right flank with $2 \times 10^{6}$ (group A) MCF-7 cells or (group B) MCF-7/Her18 cells in $0.5 \mathrm{ml}$ PBS via a 24-gauge needle. Growth of MCF-7 tumors was supplemented with $0.72 \mathrm{mg}$ of 60 -day release estrogen pellets (Innovative Research of America, Sarasota, FL, USA) which were implanted subcutaneously in the back of the animals $24 \mathrm{~h}$ prior to cell inoculation. After the appearance of a $100-\mathrm{mm}^{3}$ tumor nodule, tumor-bearing mice of group A and B were randomly divided into 5 subgroups $(\mathrm{n}=6)$ for treatment with: vehicle; i.p. injection of Taxol $(5 \mathrm{mg} / \mathrm{kg})$; Taxol $(5 \mathrm{mg} / \mathrm{kg})$ combined with CLC604 alone $(50 \mathrm{mg} / \mathrm{kg})$ or CLC604 (50 and $100 \mathrm{mg} / \mathrm{kg}$, respectively) every 5 days each week for 4 consecutive weeks. The animals were weighed, and the tumors were measured using calipers twice a week before, during, and after drug treatment. The tumor volume was calculated using the following formula: Volume $=1 / 2\left(\mathrm{Lx} \mathrm{W}^{2}\right)$, where $\mathrm{L}$ is the length and $\mathrm{W}$ is the width of the tumor. At the end of the experiments, the animals were euthanized with carbon dioxide followed by cervical dislocation.

Western blot analysis of expression of HER2 protein in vivo. Protein extracts were prepared by homogenizing tumor tissues obtained from the mice treated with vehicle, CLC604 alone, Taxol alone, and a combination of CLC604 and Taxol using a lysis buffer [20 mM Na $2 \mathrm{PO}_{4}(\mathrm{pH} 7.4), 150 \mathrm{mM} \mathrm{NaCl}, 1 \%$ Triton X-100, $1 \%$ aprotinin, $1 \mathrm{mM}$ phenylmethylsulfonyl fluo- 
A

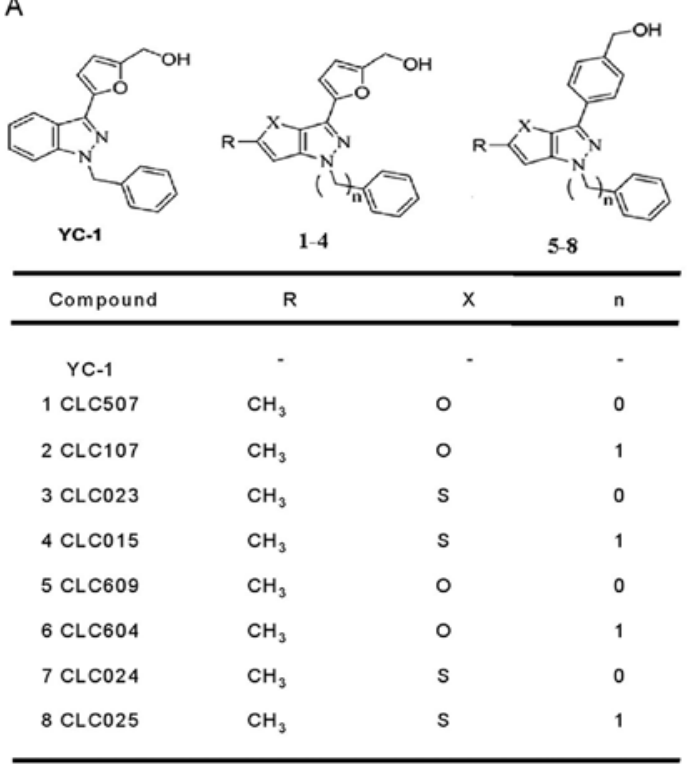

C

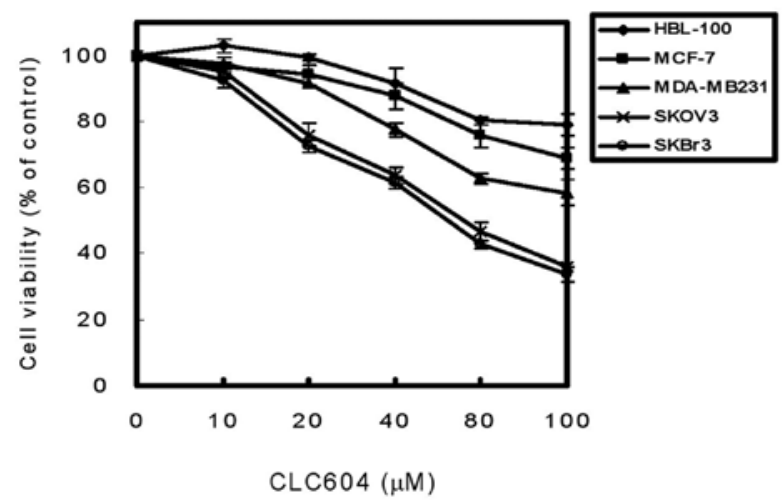

B

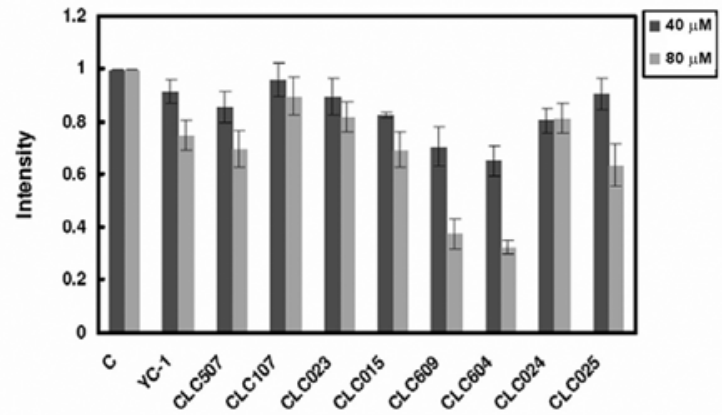

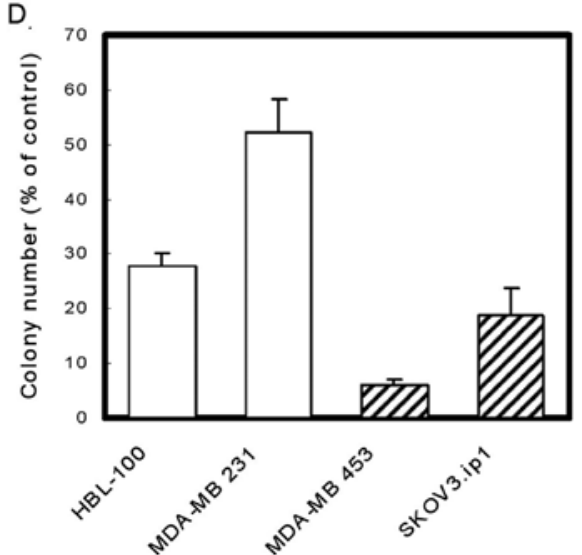

Figure 1. Effects of 1-benzyl-3-(5-hydroxymethyl-2-furyl)indazole (YC-1) and its analogues on the expression of HER2 protein. (A) Chemical structures of YC-1 and its furopyrazole and thienopyrazole isosteric analogues. (B) HER2-overexpressing breast cancer MDA-MB-453 cells were treated with YC-1 and its analogues $(40$ and $80 \mu \mathrm{M})$ at $37^{\circ} \mathrm{C}$ for $24 \mathrm{~h}$. Immunoblotting was used to measure HER 2 and $\beta$-actin. Changes in the protein expression of the bands were normalized to $\beta$-actin. Columns, mean of 3 independent experiments; bars, SD. (C) Cell viability was determined by MTT assay after continuous exposure to different concentrations of CLC604 at $37^{\circ} \mathrm{C}$ for $24 \mathrm{~h}$. The number of viable cells after treatment is expressed as a percentage of the vehicle-only control. Data point, mean of 3 independent experiments; bars, SD. (D) Effect of CLC604 on anchorage-independent growth of cancer cells. Cells (1x10 $/$ well) were seeded in a $6-\mathrm{cm}$ dish in culture medium containing $0.35 \%$ low-melting agarose over a $0.7 \%$ agarose layer in the presence of $80 \mu \mathrm{M}$ of CLC604 or control vehicle and were incubated for 3 weeks at $37^{\circ} \mathrm{C}$. Colonies larger than $100 \mu \mathrm{m}$ were counted. The percentage of colony formation was calculated by defining the number of colonies in the absence of CLC604 as 100\%. Columns, mean of 3 independent experiments; bars, SD.

ride, $10 \mathrm{mg} / \mathrm{ml}$ leupeptin, $100 \mathrm{mM} \mathrm{NaF}$ and $\left.2 \mathrm{mM} \mathrm{Na}_{3} \mathrm{VO}_{4}\right]$. The protein content was determined against a standardized control using the Bio-Rad protein assay kit (Bio-Rad Laboratories, Hercules, CA, USA). A total of $50 \mu \mathrm{g}$ of protein was processed for immunoblotting analyses as described previously (22).

Statistical analysis. All values are expressed as means \pm SD. Each value is the mean of at least 3 separate experiments for each group. ANOVA was used for statistical comparison. Values are significantly different from the control at $\mathrm{p}<0.05$, $\mathrm{p}<0.01$ and $\mathrm{p}<0.001$ as indicated in the figure legends.

\section{Results}

YC-1 and its furopyrazole and thienopyrazole isosteric analogues promote degradation of HER2. To investigate the effects of YC-1 and its furopyrazole and thienopyrazole isosteric analogues (Fig. 1A) on reducing the expression of HER2 protein, western blotting was performed to establish the HER2 protein level in HER2-overexpressing human breast cancer MDA-MB-453 cells. These results showed that the expression of HER2 in MDA-MB-453 cancer cells was suppressed by YC-1 and its analogues in a dose-dependent manner (Fig. 1B). Moreover, we found that CLC609 and CLC604 exhibited more potency in suppressing the HER2 protein level than the other analogues. Furthermore, we used the MTT growth assay to test the cytotoxicity of CLC609 and CLC604. Among them, CLC604 was found to be less cytotoxic to the immortalized noncancerous breast HBL-100 cell line (data not shown). Thus, CLC604 was considered to be most promising compound for further study. To assess the biological activity of CLC604 in terms of cell proliferation, 
cells were treated with CLC604 at different concentrations for $24 \mathrm{~h}$. The growth inhibition of the tested cell lines was in a dose-dependent manner, but to various extents (Fig. 1C). For example, CLC604 at $80 \mu \mathrm{M}$ blocked $>60 \%$ of growth in HER2-overexpressing cancer cells (SKOV3 and SKBr3). However, the inhibitory effect was much less effective in cells expressing a basal level of HER2 (MDA-MB-231, MCF-7 and HBL-100) under the same condition.

Effects of CLC604 on soft agar colony formation. Examining the effects of CLC604 on anchorage-independent growth is an important hallmark of the transformation phenotype. We seeded a variety of human cells into soft agar in the presence of a control vehicle or various concentrations of CLC604 and monitored them for colony formation. The colony-forming activity of HER2-overexpressing cancer cells (MDA-MB453 and SKOV3.ip1) was more significantly suppressed than the colony formation in cells with a basal level of HER2 (MDA-MB-231 and HBL-100) at $80 \mu \mathrm{M}$ CLC604 (Fig. 1D). The results suggest that CLC604 reduces the HER2-mediated transformation phenotype of cancer cell lines. The above results indicate that CLC604 is safe and preferentially inhibits the growth of HER2-overexpressing cancer cell lines.

CLC604 preferentially inhibits the proliferation of HER2-overexpressing cancer cells. To evaluate the effects of CLC604 on cell proliferation, MCF-7 and MDA-MB-435 cells were stably transfected with pSV2-erbB2 and then treated with $80 \mu \mathrm{M}$ CLC604 for 24 and $48 \mathrm{~h}$. The growth of these cell lines following CLC604 treatment was inhibited in a time-dependent manner (Fig. 2A and B). Treatment with $80 \mu \mathrm{M}$ CLC604 for $48 \mathrm{~h}$ inhibited over $40 \%$ of the growth in HER2-overexpressing breast cancer cell lines which stably expressed HER2 (MCF-7/HER18 and MDA-MB-435/HER2). However, the growth inhibition by CLC604 was marked lower in those parental cell lines expressing a basal level of HER2 (MCF-7 and MDA-MB-435). Conversely, CLC604 significantly inhibited the growth of HER2-overexpressing breast cancer cells, which stably expressed HER 2 as determined by cell anchorage-independent growth assay (Fig. 2C). Overall, these results suggest that CLC604 preferentially suppresses the growth of HER2-overexpressing cancer cells.

CLC604 alters the subcellular distribution of HER2. To further confirm the inhibitory effect on HER2 expression by CLC604, an immunofluorescence study with the anti-HER2 antibody (Ab-3) showed that the control cells had strong immunofluorescence at the plasma membrane (Fig. 3A). However, after CLC604 treatment, the immunofluorescence at the plasma membrane disappeared and was replaced by diffused cytoplasmic punctate staining (Fig. 3B), which may be compatible with localization in the endoplasmic reticulum or the Golgi apparatus. Moreover, MDA-MB-453 cells were treated with 17-AAG (inhibitor of Hsp90), and the immunofluorescence was also degraded (Fig. 3C), indicating that the stability of HER2 on the plasma membrane may be associated with Hsp90.

HER2-mediated resistance to CLC604-induced apoptosis. Cells transiently transfected with a human cDNA encoding HER2 (pSV2-erbB2) recovered the immunofluorescence at
A

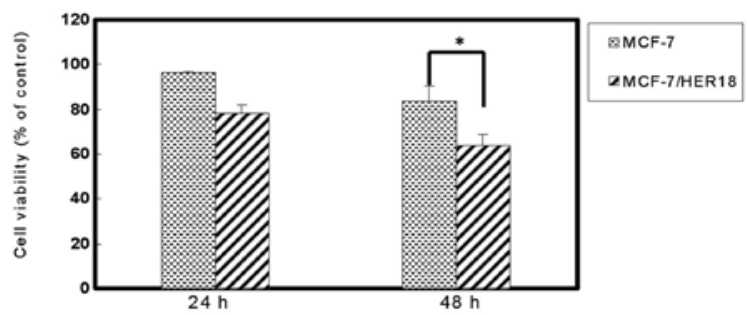

B

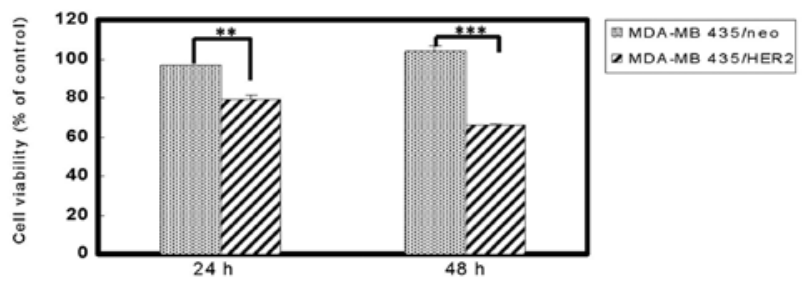

C

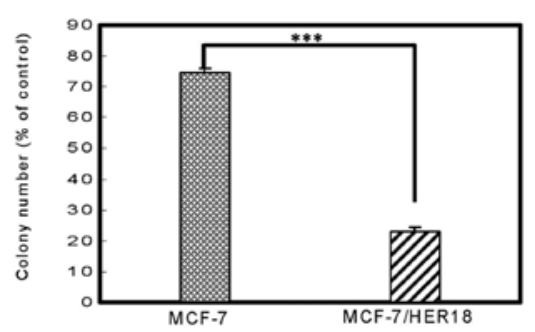

Figure 2.CLC604 treatment inhibits the proliferation of HER2-overexpressing cancer cells. (A) MCF-7 and MCF-7/HER18, (B) MDA-MB-435/neo and MDA-MB-435/HER2 cells were treated with $80 \mu \mathrm{M} \mathrm{CLC604}$ at $37^{\circ} \mathrm{C}$ for 24 and $48 \mathrm{~h}$, and the effect on cell growth was examined by MTT assay. The number of viable cells after treatment was expressed as a percentage of the vehicle-only control. (C) Effect of CLC604 on anchorage-independent growth of breast cancer cells. Column, mean of three independent experiments. Bars represent the SD. ${ }^{*} \mathrm{p}<0.05,{ }^{* *} \mathrm{p}<0.01,{ }^{* * *} \mathrm{p}<0.001$, significantly different from the control.

the membrane (Fig. 3D). This phenomenon was not observed in cells transfected with a control vector (data not shown). In addition, as shown in Fig. 3G, pSV2-erbB2-transfected MDA-MB-453 cells demonstrated high resistance to CLC604-induced apoptosis, whereas the untransfected cells progressively underwent cell death. These results indicate that CLC604 reduced HER2 protein levels and induced apoptosis in the HER2-overexpressing breast cancer cells.

CLC604 inhibits HER2 expression by decreasing HER2 stability. To delineate more effectively the mechanism of CLC604-mediated HER2 downregulation, we tested the effect of CLC604 on the HER2 protein level compared with that on the mRNA level. Combined with transcription inhibitor actinomycin D (AcD) or translation inhibitor cycloheximide (CHX), we examined the effect of CLC604 on the HER2 protein level in MDA-MB-453 breast cancer cells. The HER2 protein level was detected by immunofluorescence assay and observed by confocal microscopy. The addition of CHX (Fig. 3E) or AcD (Fig. 3F) did not significantly alter the effect of CLC604 on the immunofluorescence pattern, indicating that CLC604 treatment did not alter HER2 mRNA levels or change the rate of de novo synthesis of HER2. To determine whether HER2 degradation is accelerated by CLC604, MDA-MB-453 cells were treated with $\mathrm{CHX}$ or with a combination of $\mathrm{CHX}$ and 
Control

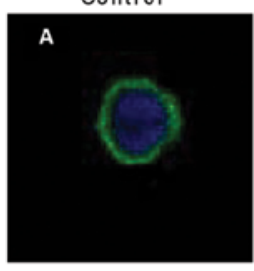

CLC604/HER2

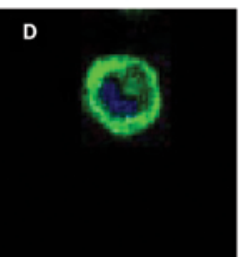

$\mathrm{CLC} 604$

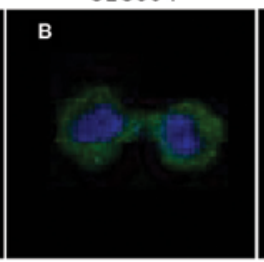

$\mathrm{CLC} 604 / \mathrm{CHX} 20 \mu \mathrm{gg} / \mathrm{ml} \quad \mathrm{CLC} 604 / \mathrm{ACD} 5 \mu \mathrm{M}$

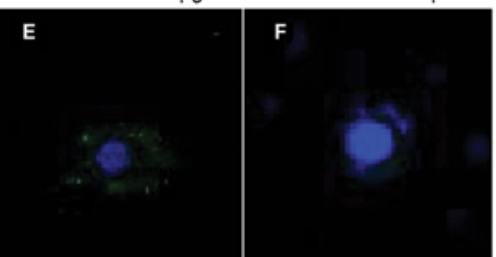

17AAG

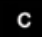

(2)

.

,

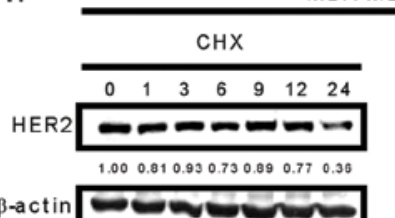

$\beta$-actin Dentorar

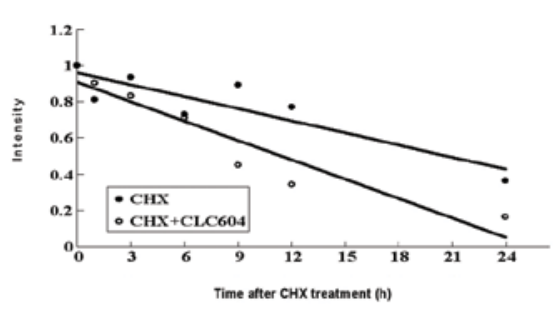

J

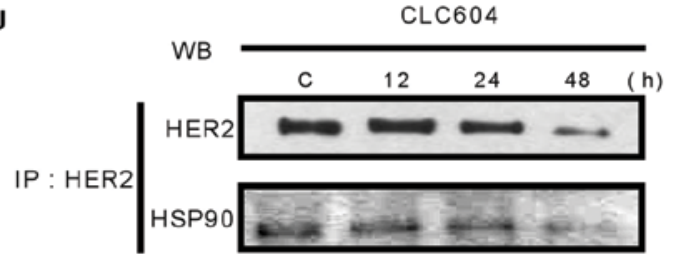
$\mathrm{CHX}+\mathrm{CLC} 604$
G

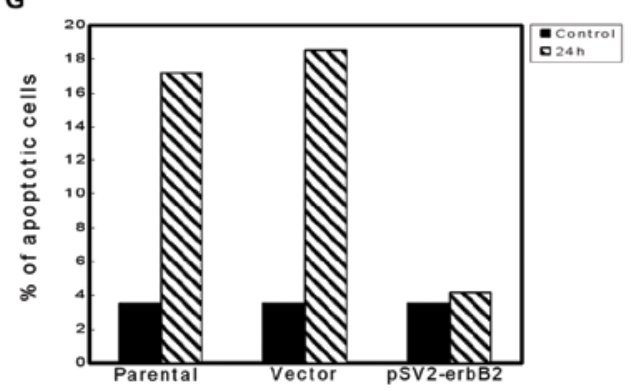

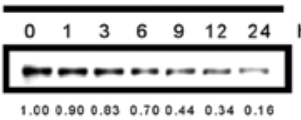

$1.000 .900 .83 \quad 0.700 .44 \quad 0.34 \quad 0.16$

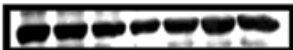

$$
\alpha-\mathrm{t}
$$

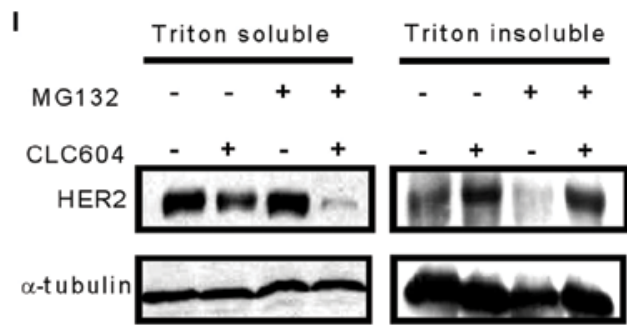

K

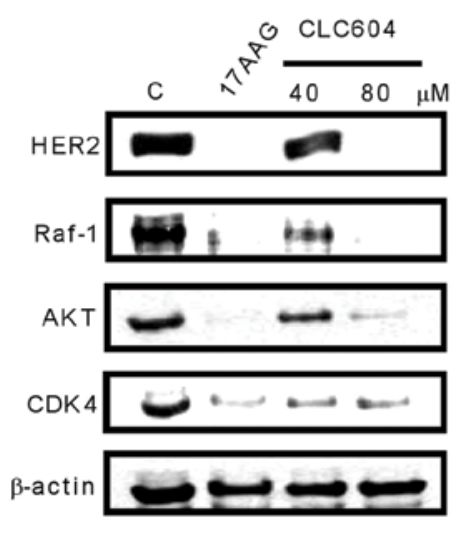

Figure 3. HER2-mediated resistance to CLC604-induced apoptosis. MDA-MB-453 cells grown on coverslips were treated with (A) control vehicle, (B) $80 \mu \mathrm{M}$ CLC604 and (C) 17-AAG $(10 \mu \mathrm{M})$ for $24 \mathrm{~h}$. (D) Cells were transfected with pSV2-erbB2 and incubated with $80 \mu \mathrm{M}$ CLC604 for $24 \mathrm{~h}$ and the percentage of apoptotic cells was determined. (E) Prior to adding $80 \mu \mathrm{M}$ CLC604, cells were pretreated with cycloheximide $20 \mu \mathrm{g} / \mathrm{ml}$ or (F) actinomycin D (AcD) $5 \mu \mathrm{M}$. Cells were fixed with $4 \%$ paraformaldehyde and stained with an HER2 antibody followed by a fluorescein isothiocyanate-conjugated secondary antibody (green) and DAPI (blue). Analysis of subcellular distribution was performed by confocal microscopy. (G) Cells were transfected with an empty vector or pSV2-erbB2 and treated with dimethyl sulfoxide (DMSO) (Con) or CLC604 (80 $\mu \mathrm{M})$ for $24 \mathrm{~h}$ and apoptosis was analyzed by flow cytometry as described in Materials and methods. (H) MDA-MB-453 cells were cultured with $20 \mu \mathrm{g} / \mathrm{ml}$ cycloheximide (CHX) in the presence or absence of $80 \mu \mathrm{M}$ CLC604 for the indicated times. Top, representative experiment in which $\beta$-actin and HER2 protein levels were assessed by western blot analysis; bottom, quantification of HER 2 expression normalized to the level of $\beta$-actin control. HER2 expression at the 0 -h time point was set as $100 \%$. (I) MDA-MB-453 cells were pretreated with MG132 $(20 \mu \mathrm{M})$ for $30 \mathrm{~min}$ followed by $80 \mu \mathrm{M}$ CLC604 for $9 \mathrm{~h}$, and Triton X-100-soluble and Triton X-100-insoluble cell lysates were prepared and assessed by western blotting with antibodies to HER2 and $\beta$-actin. (J) Dissociation of the Hsp90-HER2 complex by CLC604. SKOV3.ip1 cells were treated with $80 \mu \mathrm{M}$ CLC604 for the duration indicated. Cell lysates were immunoprecipitated with a mouse monoclonal anti-HER2 antibody and immunoblotted for HER2 and Hsp90. (K) CLC604 induced the degradation of the client proteins of Hsp90 in MDA-MB-453 breast cancer cells. MDA-MB 453 cells were treated with the Hsp90 inhibitor 17-AAG $(10 \mu \mathrm{M})$ or CLC604 $(40$ and $80 \mu \mathrm{M})$ at $37^{\circ} \mathrm{C}$ for $48 \mathrm{~h}$. Levels of HER2, Raf-1, AKT, CDK4, 17-AAG and $\beta$-actin were analyzed by western blotting. Western blotting data presented are representative of those obtained in at least 3 separate experiments.

CLC604, and the relative levels of HER2 protein in these cells were detected. As shown in Fig. 3H, the degradation rate of HER2 protein in MDA-MB-453 cells treated with CHX and CLC604 was faster than that of the cells treated only with CHX. This indicates that a posttranslational mechanism contributes to CLC604-inducd HER2 depletion in HER2- overexpressing cancer cells. To investigate further the role of proteolysis in CLC604-mediated HER2 downregulation, we conducted studies with the proteasome inhibitor MG132. In the absence of MG132, CLC604 reduced the protein levels of HER2 in both detergent (Triton X-100)-soluble and detergent (Triton X-100)-insoluble cellular fractions. MG132 was found 
(A)
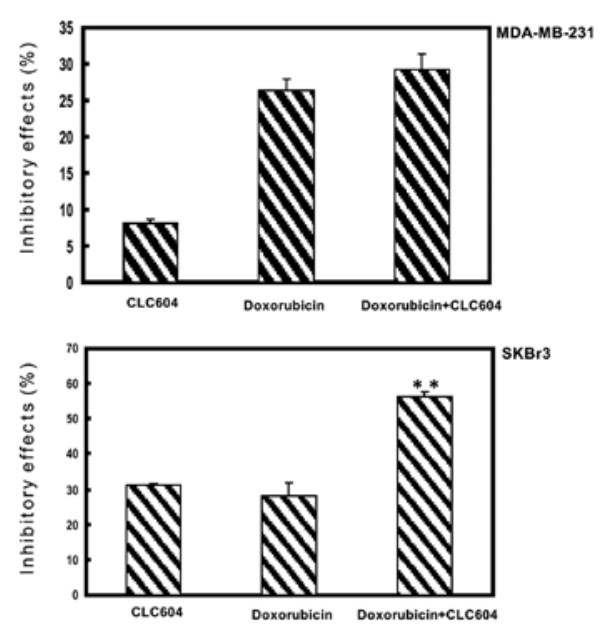

(C)
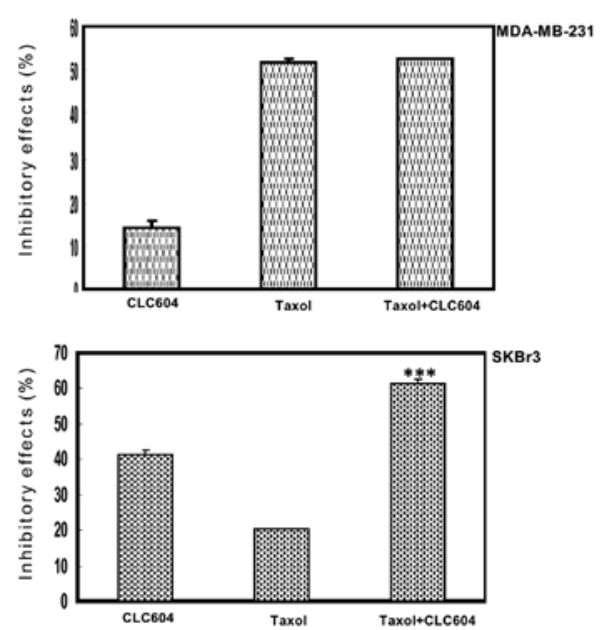

(B)
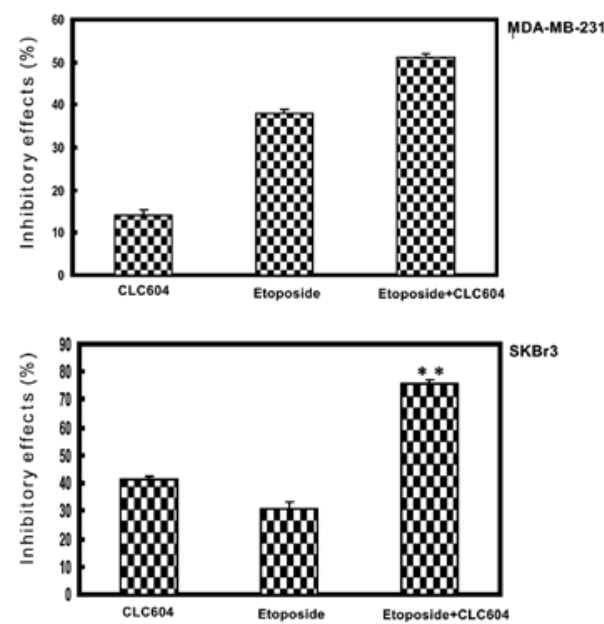

(D)
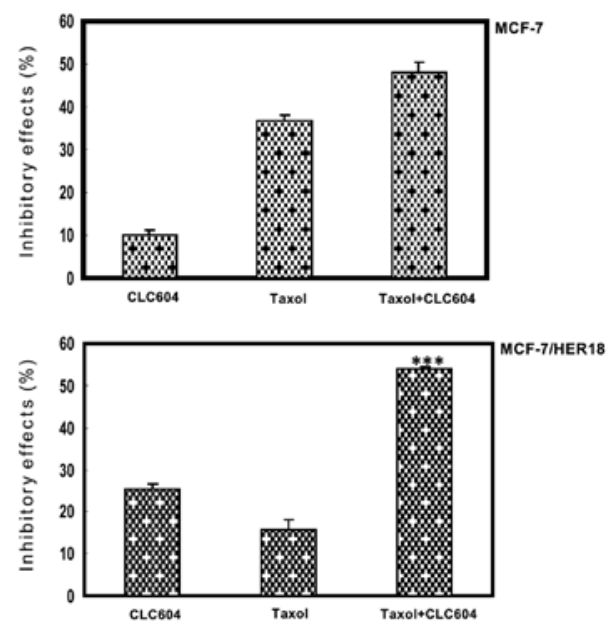

Figure 4. Effect of clinical drugs (doxorubicin, etoposide and Taxol) alone or in combination with CLC604 on the proliferation of human breast cancer cells. MDA-MB-231 and SKBr3 cells were treated with $40 \mu \mathrm{M}$ CLC604 alone or in combination with (A) $2.5 \mu \mathrm{M}$ doxorubicin, (B) $20 \mu \mathrm{M}$ etoposide, or (C) $400 \mathrm{nM}$ Taxol at $37^{\circ} \mathrm{C}$ for $24 \mathrm{~h}$. (D) MCF-7 and MCF-7/HER 18 cells were treated with $40 \mu \mathrm{M} \mathrm{CLC604}$ alone or in combination with $400 \mathrm{nM}$ Taxol at $37^{\circ} \mathrm{C}$ for $24 \mathrm{~h}$. The effects on cell growth were examined by the MTT assay, and the percentage of cell proliferation was calculated by defining the absorption of cells not treated with drugs as $100 \%$. The inhibitory effect was calculated as $100 \%$ minus the percentage of cell proliferation. Results are provided as means; bars, SD.

to inhibit CLC604-mediated reduction in HER2 levels in the Triton X-100-insoluble cellular fraction (Fig. 3I). These results suggest that proteosomal activity involves CLC604-induced HER2 degradation.

Dissociation of HER2 from Hsp90 precedes the depletion of HER2. HER2 must be bound to the Hsp90 molecular chaperone complex, which is essential for HER2 stability and maturation (25). Hsp90 is an ATP-binding protein and has $\mathrm{Mg}^{2+}$-dependent ATPase activity. To identify whether or not CLC604 disrupted the association of Hsp90 with HER2 resulting from the competition with ATP, an in vitro Hsp90 ATPase activity assay was performed. Our results showed that the efficacy of Hsp90 using ATP was inhibited by CLC604 treatment $\left(\mathrm{IC}_{50}=14.32 \pm 0.46 \mu \mathrm{M}\right)$. To study further the mechanism of HER2 depletion by disassociating it with Hsp90, MDA-MB-453 cells were treated with either the control vehicle or $80 \mu \mathrm{M}$ CLC604 at a variety of periods, and the binding of HER2 with Hsp90 was assessed. Equal amounts of fractionated proteins were immunoprecipitated with $1 \mu \mathrm{g}$ of an anti-HER2 monoclonal antibody, and the immunoprecipitates were blotted with HER2 and Hsp90 antibodies. The binding of HER2 with Hsp90 had already significantly decreased after CLC604 treatment (Fig. 3J). Moreover, Hsp90 inhibitor 17-AAG and CLC604 (40 and $80 \mu \mathrm{M}$ ) were also found to decrease the levels of client proteins of Hsp90 (HER2, Raf-1, AKT, CDK4) in MDA-MB-453 cells (Fig. 3K).

CLC604 enhances the sensitivity of doxorubicin, etoposide, and Taxol on the growth of HER2-overexpressing cancer cells. To investigate whether or not CLC604 sensitizes HER2-overexpressing cancer cells to clinical drugs, we used an MTT assay to investigate the effect of CLC604 treatment alone or in combination with doxorubicin, etoposide or Taxol on the growth of HER2-overexpressing cancer cells. To identify optimal conditions for the combination treatment, we first examined the sensitivity of the HER2-overexpressing cancer cells to doxorubicin, etoposide or Taxol. As shown in Fig. 4, 
compared with the cancer cell line that expressed low levels of HER2, the HER2-overexpressing cancer cells demonstrated greater resistance to doxorubicin (Fig. 4A), etoposide (Fig. 4B) and Taxol (Fig. C). We then examined the combined effects of CLC604 and doxorubicin, etoposide or Taxol on the growth of MDA-MB-231 cells, which express low levels of HER2, and on the growth of SKBr3 cells, which overexpress HER2. The combination of CLC604 and doxorubicin (Fig. 4A), etoposide (Fig. 4B) or Taxol (Fig. 4C) synergistically inhibited HER2-overexpressing SKBr3 cell growth. However, no significant synergistic antiproliferative effect was noted in the MDA-MB-231 cells

To investigate specifically the effects of CLC604 on HER2-induced drug resistance, we required transformed cells whose drug resistance phenotypes are induced solely by an HER2 oncogene. To achieve this, we used the MCF-7/HER18 breast cancer cell line, which stably expresses HER2. Next, we examined the effects of CLC604 on the cell growth rate. As shown in Fig. 4D, the HER2-overexpressing cancer (MCF-7/HER18) cells were much more resistant to Taxol than the parental breast cancer (MCF-7) cells. Regarding the efficacy of combinational treatment, the cytotoxicity of CLC604 when combined with Taxol in HER2-overexpressing cancer cells was obviously increased when compared to the cytotoxic effect following treatment with CLC604 or Taxol alone. These results indicate that CLC604 enhances the cytotoxic effect of clinical drugs in HER2-overexpressing cancer cells and reduces the HER2-induced drug resistance of cancer cells.

CLC604 sensitizes HER2-overexpressing tumors in SCID mice to Taxol. As mentioned above, CLC604 acts synergistically with Taxol to inhibit the growth of HER2overexpressing human breast cancer cells in vitro (Fig. 4D); we therefore examined whether CLC604 sensitizes HER2overexpressing tumors in athymic SCID mice to Taxol. MCF-7 or MCF-7/HER18 cells were injected s.c. into athymic BALB/c SCID mice. When the solid tumors became palpable, mice were treated with either control, CLC604 alone (50 and $100 \mathrm{mg} / \mathrm{kg}$, respectively), Taxol alone $(5 \mathrm{mg} / \mathrm{kg})$, or a combination of CLC604 $(50 \mathrm{mg} / \mathrm{kg})$ and Taxol $(5 \mathrm{mg} / \mathrm{kg})$ given by i.p. injection every 5 days each week for 4 consecutive weeks. As shown in Fig. 5, treatment of the MCF-7 tumor-bearing mice with Taxol alone significantly inhibited tumor growth and tumor weight (Fig. 5A and B). Moreover, the inhibitory effect on tumor growth was not enhanced by injection of CLC604 followed by Taxol (Fig. 5A and B). However, the MCF-7/HER 18 tumor-bearing mice were much more resistant to Taxol than the MCF-7 tumor-bearing mice (Fig. 6A and B). Notably, the combination treatment was significantly more effective than either of the treatments alone in MCF-7/HER 18 tumor-bearing mice (Fig. 6A and B). During evaluation of the antitumor activity, no apparent changes in mouse body weight were observed in either the treatment or the control group (Figs. 5C and 6C). These in vivo experimental results unambiguously indicate that CLC604 significantly enhances the antitumor efficacy of Taxol in HER-overexpressing tumors and efficiently reduces the HER2-induced drug resistance.

CLC604 suppresses the expression of HER2 in vivo. To investigate whether or not suppression of HER2 was associ-
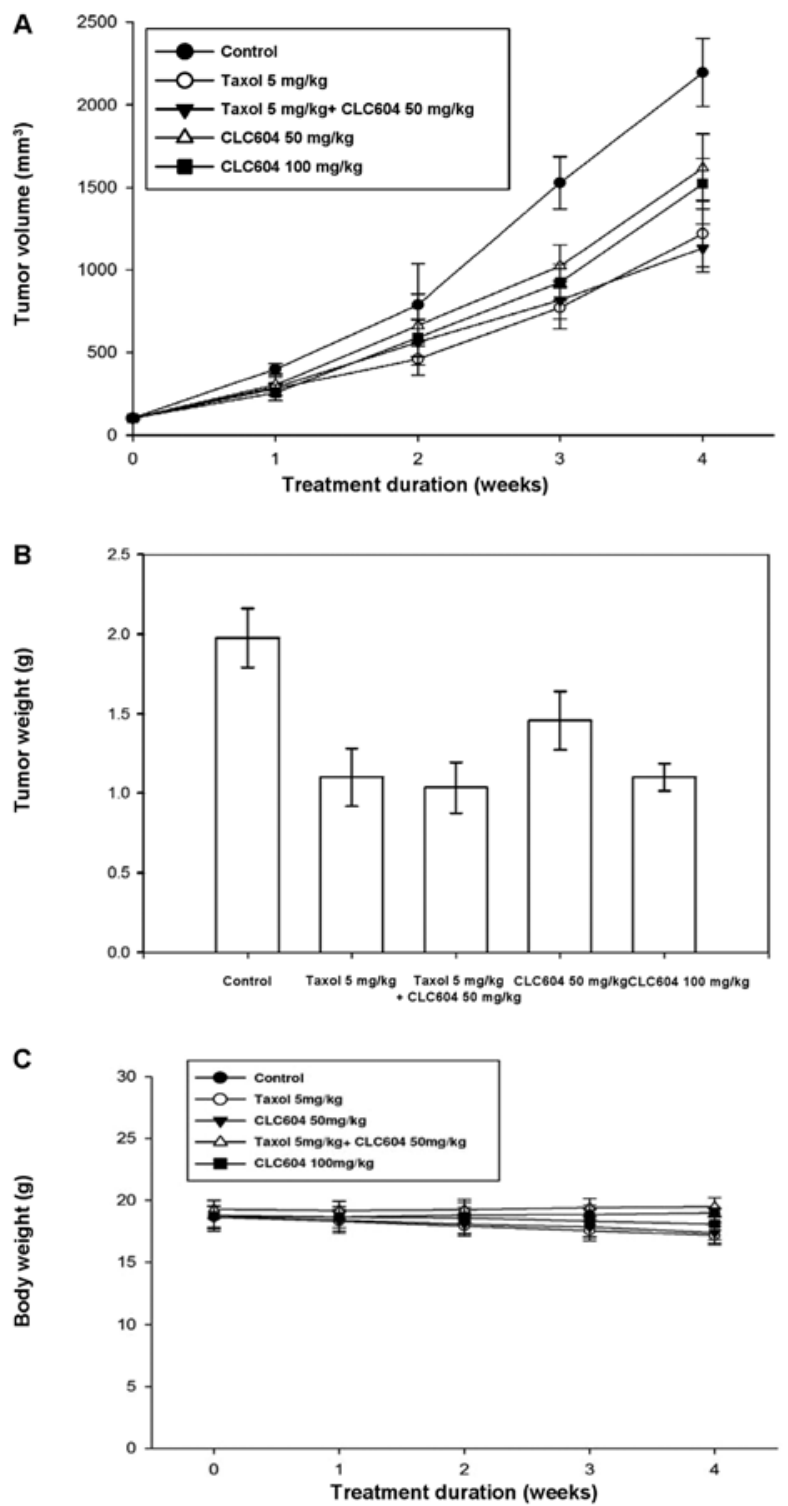

Figure 5. Effect of the treatment of CLC604 alone or in combination with Taxol in a BALB/c SCID mouse subcutaneous xenograft model. Female BALB/c SCID mice $(n=6)$ were subcutaneously inoculated with $2 \times 10^{6}$ MCF-7 cells. When the solid tumors were palpable and tumor size was measured as shown at day 0 , the mice were administered either a placebo, CLC604 (50 and $100 \mathrm{mg} / \mathrm{kg}$, respectively), Taxol $(5 \mathrm{mg} / \mathrm{kg})$, or CLC604 $(50 \mathrm{mg} / \mathrm{kg}$ ) plus Taxol $(5 \mathrm{mg} / \mathrm{kg})$ by i.p. injection every 5 days each week for 4 consecutive weeks. (A) Tumor volume $\left(\mathrm{mm}^{3}\right)$, (B) tumor weight (g), (C) body weight (g) are shown. Results are expressed as means; bars, $\mathrm{SD}$.

ated with the therapeutic effects of CLC604 on tumors in vivo, MCF-7/HER18 tumors from the mice in each group (control, CLC604 alone (50 mg/kg), Taxol alone, or CLC604 plus Taxol) were analyzed by western blot analysis. HER2 levels in the CLC604-treated tumors were barely detectable, compared with levels in the control tumors; however, HER2 levels in the Taxoltreated tumors were not significantly altered (Fig. 6D). HER2 levels in the tumors treated with CLC604 combined with Taxol were obviously markedly decreased than levels in the tumors treated with CLC604 or Taxol alone. These results indicate that CLC604 suppresses the growth of HER2-overexpressing tumors in SCID mice by inhibiting the expression of HER2 and reduces the HER2-induced drug resistance of cancer cells. 

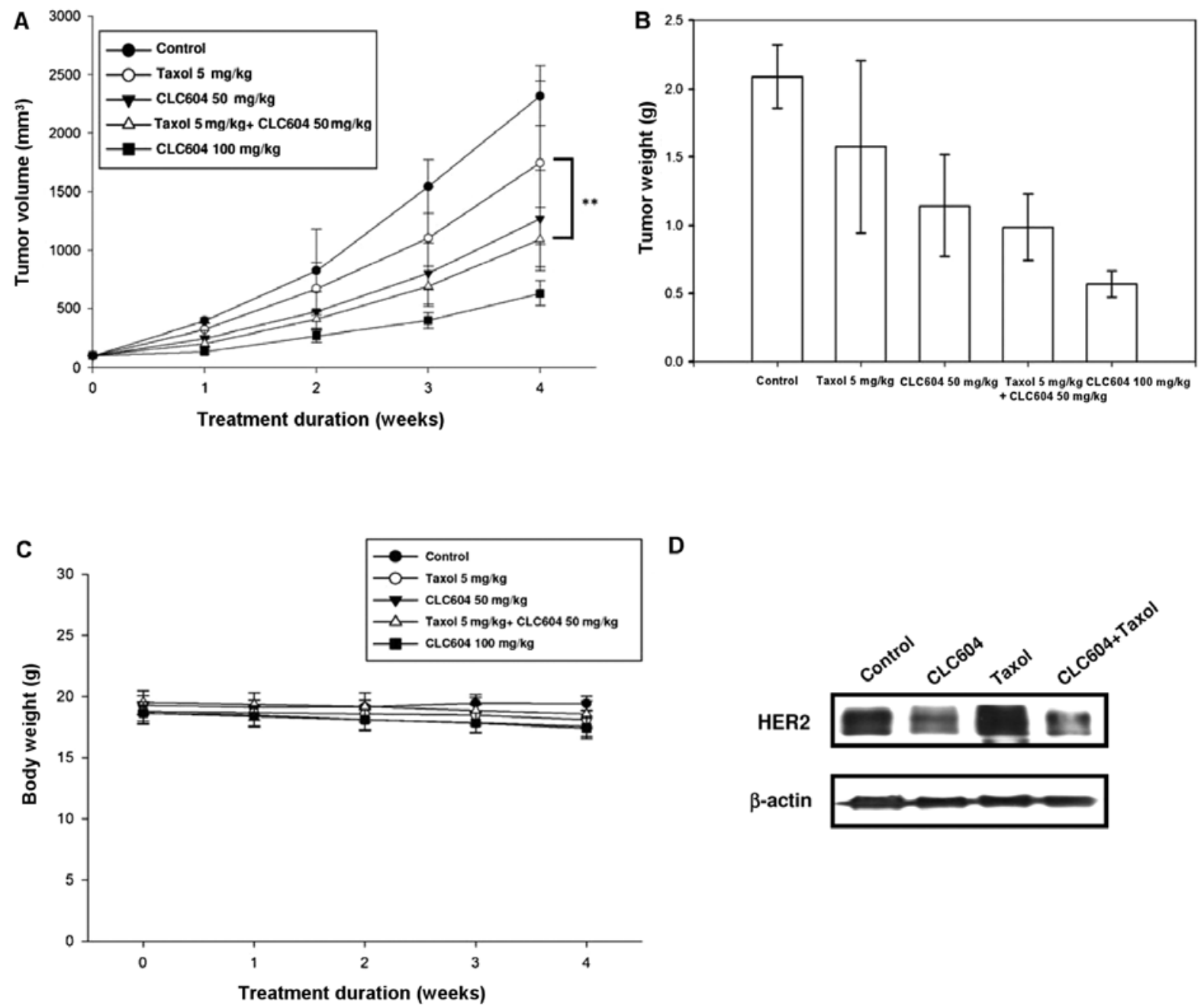

D

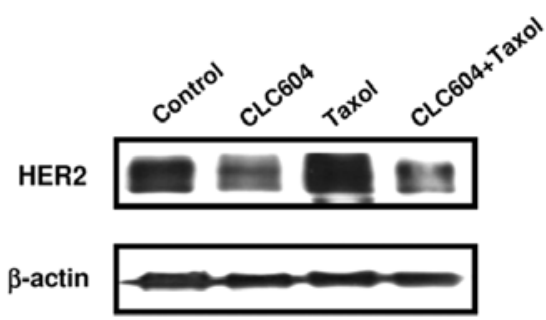

Figure 6. Effect of CLC604 alone or in combination with Taxol in the HER2-overexpressing BALB/c SCID mouse subcutaneous xenograft model. Female $\mathrm{BALB} / \mathrm{c}$ SCID mice $(\mathrm{n}=6)$ were subcutaneously inoculated with $2 \times 10^{6} \mathrm{MCF}-7 / \mathrm{HER} 18 \mathrm{cells}$. When the solid tumors were palpable and tumor size was measured as shown at day 0, the mice were given either a placebo, CLC604 (50 and $100 \mathrm{mg} / \mathrm{kg}$, respectively), Taxol (5 mg/kg), or CLC604 (50 mg/kg) plus Taxol $\left(5 \mathrm{mg} / \mathrm{kg}\right.$ ) by i.p. injection every 5 days each week for 4 consecutive weeks. (A) Tumor volume $\left(\mathrm{mm}^{3}\right)$, (B) tumor weight (g), (C) body weight (g) are shown. Results are expressed as means; bars, SD. (D) Western blot analysis of levels of HER2 protein in vivo. Protein extracts were prepared by homogenizing tumor tissues obtained from the control, CLC604-treated, Taxol-treated, and combined CLC604 and Taxol-treated mice with lysis buffer. Western blotting was conducted using an anti-HER2 antibody or an anti- $\beta$-actin antibody, as described in 'Materials and methods'.

\section{Discussion}

In the present study, we examined the relationship between the chemical structures and the inhibitory activity of YC-1 and its furopyrazole and thienopyrazole isosteric analogues on the expression of HER 2 protein. We identified that 1 of the 8 derivatives, CLC604, was more effective than the other derivatives, even more than YC-1 in suppressing the HER2 protein level. We demonstrated that CLC604 preferentially inhibited the growth of HER2-overexpressing cancer cells, but not the cell lines expressing basal levels of HER2, and suppressed the transformation phenotype induced by HER2 overexpression. Moreover, CLC604 was also found to be more effective in inhibiting the proliferation of HER2-overexpressing cancer cells, which were stably transfected with pSV2-erbB2, when compared with breast cancer cells expressing basal levels of HER2.

Resent studies have demonstrated that constitutive phosphorylation of HER2 is associated with resistance to systemic therapies and local radiation therapies. Activation of HER2-containing heterodimers results in receptor autophosphorylation on $\mathrm{COOH}$-terminal tyrosine residues, which become the docking sites for a number of signal transducers and adaptor molecules that initiate a plethora of signaling programs leading to cell proliferation, differentiation, migration, adhesion, protection from apoptosis and transformation, among other effects. Our present study showed that HER2 is essential for cell survival. We treated HER2-overexpressing breast cancer MDA-MB-453 cells with $80 \mu \mathrm{M}$ CLC604, and the cell survival rate was detected by flow cytometry and compared with MDA-MB-453 cells transiently transfected with pSV2-erbB2. These results demonstrated that pSV2-erbB2-transfected MDA-MB-453 cells exhibited high resistance to CLC604-induced apoptosis, whereas the untransfected cells progressively underwent cell death. This is consistent with a recent report that HER2-overexpressing cancer cells are dependent on HER2 levels for survival and, thus, are more sensitive to treatments that target HER2. 
In previous studies, YC-1 has been identified as a novel class of NO-dependent stimulators of soluble gualylate cyclase (sGC) that exhibit therapeutic potential for the treatment of a range of vascular diseases, including hypertension, thrombosis, erectile dysfunction, and postangioplasty restenosis $(14,26,27)$. Currently, YC-1 has been proven to suppress proliferation of HA22T cells through $\mathrm{G}_{0}-\mathrm{G}_{1}$ arrest via inhibition of CDK2 and CDK4 by upregulation of $\mathrm{p} 21^{\mathrm{CIP} 1 / \mathrm{WAP} 1}$ and $\mathrm{p} 27^{\mathrm{KIP} 1}$ (28). Furthermore, YC-1 was observed to suppress NF- $\kappa$ B activity via inhibition of the phosphorylation and degradation of I- $\kappa \mathrm{B} \alpha$ and to induce apoptosis in prostate cancer PC-3 cells (17). Moreover, YC-1 was recognized to inhibit angiogenesis via repression of VEGF by downregulating HIF-1 resulting in reducing cancer cell proliferation (16,29-31). In the present study, our results showed that YC-1 repressed the protein level of HER2. Interestingly, we found that its isosteric analogue, CLC604, was more effective than YC-1 and its known derivatives in repressing the protein level of HER2. Moreover, CLC604 preferentially inhibited the growth of HER2-overexpressing cancer cells.

Hsp90 is required for refolding unfolded proteins and for cellular survival under environmental stress, and plays a key role in transducing proliferative and anti-apoptotic signals particularly in tumor cells; but in normal tissues, Hsp90 exists in a free, uncomplexed, or latent state (32). Consequently, inhibition of Hsp90 has emerged as a possible strategy for the treatment of advanced cancers (10). Research found that the benzoquinone ansamycins such as geldanamycin and other Hsp90 inhibitors, such as 17-AAG, enhanced the intracellular degradation of HER2 which involved targeting of the Hsp90 (13). Hsp90 forms complexes with HER2 and other client proteins. Recently, the mechanistic basis of Hsp90 client proteins sensitive to $17-\mathrm{AAG}$ has been demonstrated. The data of client protein half-life has showed that HER2 $<$ mutant EGFR $<$ Raf-1 < Akt < mutant BRAF < wild-type EGFR or HER2 is more sensitive to $17-\mathrm{AAG}$ than other client proteins (33). Once 17-AAG blocks ATP binding to Hsp90, the chaperone complex associated with the client protein is biased toward a degradative fate, resulting in polyubiquitylation and subsequent destruction of the client. The mature HER2 requires Hsp90 association with its kinase domain to maintain the conformation necessary to heterodimerize with other ligand-activated HER proteins.

Our present study found that the HER2 protein level decreased more rapidly in cells treated with $\mathrm{CHX}$ plus CLC604 than in cells treated with $\mathrm{CHX}$ alone. This result suggests that a post-translational mechanism contributes to CLC604-induced HER2 instability and depletion in HER2overexpressing cancer cells. We then attempted to identify whether or not CLC604 disrupts the association of Hsp90 with HER2 resulting from competition with ATP. Our in vitro Hsp90 ATPase activity assay showed that the efficacy of Hsp90 was inhibited by CLC604 treatment. CLC604 dissociated the complex between HER2 and Hsp90, and such dissociation precedes the depletion of mature HER2 at the plasma membrane. The depletion of mature membrane HER 2 and the concomitant accumulation of HER2 in the cytoplasmic organelles are compatible with the notion that the complex of HER2 with Hsp90 is necessary for its maturation and subsequent transport to the plasma membrane. We thus hypothesized that
CLC604 may also disrupt the association of HER2 and the chaperone complex through competition with ATP, and this may explain why CLC604 can deplete HER2 protein. Aside from HER2, other Hsp90 client proteins, such as Akt, c-Raf and CDK4, were also reduced by CLC604.

Recently, research has suggested that HER2-overexpressing cancer cells develop drug resistance and relapse capacity following treatment with clinical drugs (34). This supports the notion that HER2 overexpression is associated with chemoresistance. Moreover, data from clinical trials in breast cancer also suggest an association between HER2 overexpression and resistance to chemotherapy (35-38). Their results indicate that node-negative breast cancer patients whose tumors contains HER2 overexpression have a less favorable prognosis due to a lack of response to adjuvant cyclophosphamide, methotrexate, and 5-fluorouracil-based chemotherapy. A study of HER2 overexpression in epithelial ovarian cancer also demonstrated that patients whose tumors had the HER2 alteration were more likely to have a failed response to chemotherapy with cyclophosphamide and carboplatin (39). These reports support the notion that HER2 overexpression is associated with chemoresistance.

In the present study, we demonstrated that CLC604 was able to sensitize SKBr3 and MCF-7/HER18 breast cancer cells which overexpress HER2 to the anticancer drugs doxorubicin, etoposide and Taxol in vitro, but did not have the same effect on the MDA-MB-231 and MCF-7 cell lines, which express basal levels of HER2. These results suggest that HER2 is required for cell growth and promotes doxorubicin, etoposide and Taxol resistance; and tumor suppression by CLC604 alone and the synergistic effect of CLC604 plus Taxol on tumor growth in mice may be due to decreased HER2. In the mice with HER2overexpressing MCF-7/HER18 tumors, CLC604 significantly reduced tumor volume and weight. Western blot analysis indicated that the HER2 level was significantly reduced in the tumors by CLC604 treatment when compared with the control treatment. These results indicate that CLC604 functions as an Hsp90 inhibitor and causes HER2-overexpressing cancer cells to become sensitized to Taxol in vivo. Our data corroborated a previous report that higher efficiency was obtained when combining treatment with 17-AAG, an Hsp90 inhibitor, causing cancer cells to become sensitive to Taxol specifically and other clinical drugs when treating HER2-overexpressing cancer (40).

Taken together, the central and novel findings in the present study are that i) CLC604 is more effective than YC-1 and its known derivatives; ii) CLC604 decreases the expression level of HER2 in HER2-overexpressing cancer cells in vitro; iii) CLC604 significantly suppresses the growth of HER2overexpressing cancer cells and transformed breast cancer cells in soft agarose; iv) CLC604 decreases the protein halflife of HER2 by proteasome activity; and v) CLC604 may act as an Hsp90 inhibitor and cause HER2-overexpressing cancer cells to become sensitive to Taxol, doxorubicin and etoposide. The above findings may help improve the efficacy of preventive or therapeutic compounds against HER2-overexpressing cancer cells.

\section{Acknowledgements}

The investigation was supported by a research grants from the National Science Council (NSC 101-2325-B-039-005) to 
S.C. Kuo. Thanks are also due for the support (in part) by a grant from the Department of Health (Taiwan), China Medical University Hospital Cancer Research Center of Excellence (DOH100-TD-C-111-005) and a grant from the China Medical University (CMU100-TS-10). We thank Professor Mien-Chie Hung (The University of Texas M.D. Anderson Cancer Center, Houston, TX, USA) for generously providing cancer cell lines MDA-MB 453/neo, MDA-MB 435/HER2 and MCF-7/HER18.

\section{References}

1. Stearns V, Schneider B, Henry NL, Hayes DF and Flockhart DA Breast cancer treatment and ovarian failure: risk factors and emerging genetic determinants. Nat Rev Cancer 6: 886-893, 2006.

2. Chiang CT, Way TD and Lin JK: Sensitizing HER2overexpressing cancer cells to luteolin-induced apoptosis through suppressing $\mathrm{p} 21^{\mathrm{WAF} / \mathrm{ClP} 1}$ expression with rapamycin. Mol Cancer Ther 6: 2127-2138, 2007.

3. Slamon DJ, Clark GM, Wong SG, Levin WJ, Ullrich A and McGuire WL: Human breast cancer: correlation of relapse and survival with amplification of the HER-2/neu oncogene. Science 235: 177-182, 1987.

4. Yu D and Hung MC: Overexpression of ErbB2 in cancer and ErbB2-targeting strategies. Oncogene 19: 6115-6121, 2000.

5. Meric-Bernstam F and Hung MC: Advances in targeting human epidermal growth factor receptor-2 signaling for cancer therapy. Clin Cancer Res 12: 6326-6330, 2006.

6. Esteva FJ, Yu D, Hung MC and Hortobagyi GN: Molecular predictors of response to trastuzumab and lapatinib in breast cancer. Nat Rev Clin Oncol 7: 98-107, 2010.

7. Vogel CL, Cobleigh MA, Tripathy D, et al: Efficacy and safety of trastuzumab as a single agent in first-line treatment of HER2-overexpressing metastatic breast cancer. J Clin Oncol 20 719-726, 2002

8. Cardoso F, Piccart MJ, Durbecq V and Di Leo A: Resistance to trastuzumab: a necessary evil or a temporary challenge? Clin Breast Cancer 3: 247-257, 2002.

9. Lan KH, Lu CH and Yu D: Mechanisms of trastuzumab resistance and their clinical implications. Ann NY Acad Sci 1059: 70-75, 2005.

10. Trepel J, Mollapour M, Giaccone G and Neckers L: Targeting the dynamic HSP90 complex in cancer. Nat Rev Cancer 10: 537-549, 2010.

11. Xu W, Mimnaugh E, Rosser MF, Nicchitta C, Marcu M, Yarden Y and Neckers L: Sensitivity of mature Erbb2 to geldanamycin is conferred by its kinase domain and is mediated by the chaperone protein Hsp90. J Biol Chem 276: 3702-3708, 2001.

12. Richter K, Reinstein J and Buchner J: A Grp on the Hsp90 mechanism. Mol Cell 28: 177-179, 2007.

13. Solit DB, Zheng FF, Drobnjak M, et al: 17-Allylamino-17demethoxygeldanamycin induces the degradation of androgen receptor and HER-2/neu and inhibits the growth of prostate cancer xenografts. Clin Cancer Res 8: 986-993, 2002.

14. Ko FN, Wu CC, Kuo SC, Lee FY and Teng CM: YC-1, a novel activator of platelet guanylate cyclase. Blood 84: 4226-4233, 1994.

15. Chou LC, Huang LJ, Yang JS, Lee FY, Teng CM and Kuo SC: Synthesis of furopyrazol analogs of 1-benzyl-3-(5-hydroxymethyl-2-furyl)indazole (YC-1) as novel anti-leukemia agents. Bioorg Med Chem 15: 1732-1740, 2007.

16. Pan SL, Guh JH, Peng CY, et al: YC-1 [3-(5'-hydroxymethyl2'-furyl)-1-benzyl indazole] inhibits endothelial cell functions induced by angiogenic factors in vitro and angiogenesis in vivo models. J Pharmacol Exp Ther 314: 35-42, 2005.

17. Huang YT, Pan SL, Guh JH, Chang YL, Lee FY, Kuo SC and Teng CM: YC-1 suppresses constitutive nuclear factor- $\kappa \mathrm{B}$ activation and induces apoptosis in human prostate cancer cells. Mol Cancer Ther 4: 1628-1635, 2005.

18. Chun YS, Yeo EJ, Choi E, Teng CM, Bae JM, Kim MS and Park JW: Inhibitory effect of YC-1 on the hypoxic induction of erythropoietin and vascular endothelial growth factor in Hep3B cells. Biochem Pharmacol 61: 947-954, 2001.

19. Mujoo K, Sharin VG, Bryan NS, et al: Role of nitric oxide signaling components in differentiation of embryonic stem cells into myocardial cells. Proc Natl Acad Sci USA 105: 18924-18929, 2008 .
20. Yun S, Lee SH, Kang YH, et al: YC-1 enhances natural killer cell differentiation from hematopoietic stem cells. Int Immunopharmacol 10: 481-486, 2010.

21. Chou LC, Huang LJ, Hsu MH, et al: Synthesis of 1-benzyl3-(5-hydroxymethyl-2-furyl)selenolo[3,2-c]pyrazole derivatives as new anticancer agents. Eur J Med Chem 45: 1395-1402, 2010.

22. Way TD, Lee JC, Kuo DH, et al: Inhibition of epidermal growth factor receptor signaling by Saussurea involucrata, a rare traditional Chinese medicinal herb, in human hormone-resistant prostate cancer PC-3 cells. J Agric Food Chem 58: 3356-3365, 2010.

23. Lin VC, Chou CH, Lin YC, et al: Osthole suppresses fatty acid synthase expression in HER2-overexpressing breast cancer cells through modulating Akt/mTOR pathway. J Agric Food Chem 58: 4786-4793, 2010.

24. Panaretou B, Prodromou C, Roe SM, O'Brien R, Ladbury JE, Piper PW and Pearl LH: ATP binding and hydrolysis are essential to the function of the Hsp90 molecular chaperone in vivo. EMBO J 17: 4829-4836, 1998

25. Oude Munnink TH, Korte MA, Nagengast WB, et al: $89 \mathrm{Zr}$-trastuzumab PET visualises HER2 downregulation by the HSP90 inhibitor NVP-AUY922 in a human tumour xenograft. Eur J Cancer 46: 678-684, 2010.

26. Evgenov OV, Pacher P, Schmidt PM, Haskó G, Schmidt HH and Stasch JP: NO-independent stimulators and activators of soluble guanylate cyclase: discovery and therapeutic potential. Nat Rev Drug Discov 5: 755-768, 2006.

27. Liu XM, Peyton KJ, Mendelev NN, Wang H, Tulis DA and Durante W: YC-1 stimulates the expression of gaseous monoxide-generating enzymes in vascular smooth muscle cells. Mol Pharmacol 75: 208-217, 2009.

28. Wang SW, Pan SL, Guh JH, et al: YC-1 [3-(5'-Hydroxymethyl-2'furyl)-1-benzyl indazole] exhibits a novel antiproliferative effect and arrests the cell cycle in G0-G1 in human hepatocellular carcinoma cells. J Pharmacol Exp Ther 312: 917-925, 2005.

29. Yeo EJ, Chun YS, Cho YS, Kim J, Lee JC, Kim MS and Park JW: YC-1: a potential anticancer drug targeting hypoxia-inducible factor 1. J Natl Cancer Inst 95: 516-525, 2003.

30. Yeh WL, Lu DY, Lin CJ, Liou HC and Fu WM: Inhibition of hypoxia-induced increase of blood-brain barrier permeability by $\mathrm{YC}-1$ through the antagonism of HIF- $1 \alpha$ accumulation and VEGF expression. Mol Pharmacol 72: 440-449, 2007.

31. Zhao Q, Du J, Gu H, Teng X, Zhang Q, Qin H and Liu N: Effects of $\mathrm{YC}-1$ on hypoxia-inducible factor 1-driven transcription activity, cell proliferative vitality, and apoptosis in hypoxic human pancreatic cancer cells. Pancreas 34: 242-247, 2007.

32. Kamal A, Thao L, Sensintaffar J, Zhang L, Boehm MF, Fritz LC and Burrows FJ: A high-affinity conformation of Hsp90 confers tumour selectivity on Hsp90 inhibitors. Nature 425: 407-410, 2003.

33. Sawai A, Chandarlapaty S, Greulich H, et al: Inhibition of Hsp90 down-regulates mutant epidermal growth factor receptor (EGFR) expression and sensitizes EGFR mutant tumors to paclitaxel. Cancer Res 68: 589-596, 2008.

34. Morrow PK, Zambrana F and Esteva FJ: Recent advances in systemic therapy: advances in systemic therapy for HER2-positive metastatic breast cancer. Breast Cancer Res 11: 207, 2009.

35. Allred DC, Clark GM, Tandon AK, et al: HER-2/neu in nodenegative breast cancer: prognostic significance of overexpression influenced by the presence of in situ carcinoma. J Clin Oncol 10: $599-605,1992$

36. Harris JR, Lippman ME, Veronesi U and Willett W: Breast cancer (1). N Engl J Med 327: 319-328, 1992.

37. Harris JR, Lippman ME, Veronesi U and Willett W: Breast cancer (2). N Engl J Med 327: 390-398, 1992.

38. Harris JR, Lippman ME, Veronesi U and Willett W: Breast cancer (3). N Engl J Med 327: 473-480, 1992.

39. Felip E, Del Campo JM, Rubio D, Vidal MT, Colomer R and Bermejo B: Overexpression of c-erbB-2 in epithelial ovarian cancer. Prognostic value and relationship with response to chemotherapy. Cancer 75: 2147-2152, 1995.

40. Ramalingam SS, Egorin MJ, Ramanathan RK, et al: A phase I study of 17-allylamino-17-demethoxygeldanamycin combined with Taxol in patients with advanced solid malignancies. Clin Cancer Res 14: 3456-3461, 2008 